\title{
TARGET PERTUMBUHAN INVESTASI DAN RENCANA STRATEGI PENGEMBANGAN INVESTASI PROVINSI PAPUA
}

\author{
Penulis: \\ Marsi Adi Purwadi ${ }^{1}$ \\ marsipurwadi@ieuncen.ac.id \\ Yundy Hafizrianda ${ }^{2}$ \\ apitika@yahoo.com \\ Ida Ayu Purba Riani ${ }^{3}$ \\ purbariani@gmail.com
}

\begin{abstract}
In general intent and purpose of this study is to give an overview of investment policy direction in Papua province in relation to improving the economic growth both sectoral and regional basis. Some quantitative methods used are macroregional regional development planning models such as growth models, COR and ICOR. The required data is covered by a documentation method sourced from a competent agency.

Where the results of this study indicate that: 1) It is seen that spatially, out of the 29 districts or cities the ICOR has been calculated, there are 20 regions considered to have low cost to investment because they have a low ICOR; 2) Based on the ICOR analysis, it was found that during the period of 2012-2016 the most inefficient economic sector in Papua Province was the industrial sector; 3) Referring to the very low ICOR magnitude with an average below 4, it is finally generalized that efforts to increase regional investment in Papua Province in the future should be directed to agriculture-based sectors.
\end{abstract}

Keywords : Investment, ICOR, Economic Growth

\section{PENDAHULUAN}

Perkembangan investasi yang merupakan salah satu indikator kemajuan pertumbuhan ekonomi di Indonesia, dimana investasi yang dilakukan secara tepat dapat mendukung peningkatan kesejahteraan masyarakat Indonesia. Tantangan pelaksanaan investasi di Indonesia saat ini, salah satunya adalah dengan pemberlakuan otonomi daerah di Indonesia. Sejak tahun 2001 era otonomi daerah di Indonesia dimulai, dimana semenjak berlakunya Undang-Undang Nomor 22 Tahun 1999

\footnotetext{
${ }^{1}$ Staf Dosen Jurusan IImu Ekonomi Universitas Cenderawasih

2 Staf Dosen Jurusan IImu Ekonomi Universitas Cenderawasih

${ }^{3}$ Staf Dosen Jurusan IImu Ekonomi Universitas Cenderawasih
} 
tentang Pemerintah Daerah dan kemudian diperbaharui dengan UndangUndang Nomor 23 Tahun 2014. Sementara itu, sumber pendanaannya diatur dalam Undang-Undang Nomor 25 Tahun 1999 tentang Perimbangan Keuangan antara Pemerintah Pusat dan Pemerintah Daerah, yang kemudian diperbaharui dengan Undang-Undang Nomor 33 Tahun 2004. Dimana makna penting pengaturan tersebut adalah bahwa ada sistem pembagian keuangan yang adil, proporsional, demokratis, transparan, dan efisien dalam rangka penyelenggaraan desentralisasi dengan mempertimbangkan potensi, kondisi, dan kebutuhan daerah serta besaran pendanaan penyelenggaraan dekonsentrasi dan tugas pembantuan.

Dalam konteks peraturan tentang otonomi daerah yang demikian, maka diatur pula bahwa pemberian sumber keuangan negara kepada Pemerintah Daerah dalam rangka pelaksanaan desentralisasi didasarkan atas penyerahan tugas oleh Pemerintah kepada Pemerintah Daerah dengan memperhatikan stabilitas dan keseimbangan fiskal.

Menurut Adisasmita (2010), bahwa setiap daerah perlu menempuh kebijakan yang sesuai karakteristik spesifik masing-masing daerah. Pertanyaan yang kemudian dapat diajukan adalah bagaimana dengan investasi yang dilakukan di era otonomi daerah, terutama dalam kaitannya dengan problematika keuangan daerah.

Persoalan ini adalah persoalan yang sangat menentukan dalam perkembangan investasi daerah, terutama bilamana investasi tersebut berkaitan dengan struktur anggaran pemerintah daerah, pengelolaannya, serta pertanggungjawabannya. Penanaman modal di daerah juga berimplikasi pada bagaimana interaksi hukum otonomi daerah dengan hukum investasi itu sendiri di Indonesia khususnya pada wilayah Provinsi Papua.

Dampak terhadap laju pertumbuhan ekonomi Papua dalam 5 tahun terakhir ini (2012-2016) cukup mengesankan mencapai 6,21\% per tahun. Bahkan untuk 2 tahun sebelumnya (2014-2016) Provinsi Papua mampu mencetak prestasi terbaik dalam meningkatkan pertumbuhan ekonomi, yaitu 
dari 3,46\% di tahun 2014, melonjak tinggi menjadi 9,21\% di tahun 2016, yang berada di urutan ke-2 tertinggi di Indonesia. Dengan rata-rata pertumbuhan kesempatan kerja sebesar 2,23\% per tahun untuk periode yang sama, ini berarti $1 \%$ pertumbuhan ekonomi yang diciptakan mampu meningkatkan peluang lapangan kerja sebesar $0,36 \%$ per tahun. Hal ini menghasilkan Tingkat Pengangguran Terbuka (TPT) di Provinsi Papua cenderung rendah, dan terlihat lebih kecil dibandingkan Indonesia secara keseluruhan. Sebagai misal untuk tahun 2016, TPT di Provinsi Papua hanya 3,35\%, sedangkan Indonesia sebesar $5,61 \%$. Dengan kata lain jumlah orang yang bekerja di Papua dari seluruh angkatan kerja yang tersedia rata-rata mencapai $96,65 \%$ (Bank Indonesia, 2016).

Walaupun demikian, karena serapan tenaga kerja lebih banyak berada pada sektor pertanian, kurang lebih $75 \%$ per tahun, dengan tingkat upah riilnya paling cukup rendah, menyebabkan pendapatan per kapita di Papua tampak paling rendah di Indonesia (Rp. 35,87 juta per kapita), dan mempunyai kemiskinan tertinggi di Indonesia (28,40\%). Fenomena ini sendiri mengindikasikan bahwa pertumbuhan ekonomi yang terjadi selama ini belum mampu memberi transfer payment yang maksimal terhadap tingkat kesejahteraan penduduk.

Salah satu penyebab mengapa kondisi ini dapat terjadi adalah karena adanya ketimpangan ekonomi yang sangat tinggi di Provinsi Papua selama ini. Dimana secara sektoral dapat dilihat pada pondasi perekonomian yang sangat bertumpu pada satu sektor dominan saja yaitu pertambangan. Bukan hanya terhadap nilai tambah regional $( \pm 43 \%)$, namun juga pada struktur investasi $( \pm 34,64 \%)$ dan ekspor $( \pm 91 \%)$ terlihat sektor pertambangan (khususnya tambang bijih tembaga) sangat mendominasi. Selama masa pembangunan di Papua sektor pertambangan juga belum banyak berperan sebagai leading sektor.

Ketimpangan berikutnya yang mencolok di Provinsi Papua adalah ketimpangan antarwilayah. Dimana selama ini hanya ada dua wilayah di Provinsi Papua yang paling berperan terhadap perekonomian Papua yaitu 
Kabupaten Mimika dan Kota Jayapura. Namun kedua wilayah tersebut tidak banyak memberi trickle down effect bagi wilayah-wilayah sekitar lainnya. Kemudian muncul pertanyaan tentang investasi yang dilakukan di era otonomi daerah, terutama dalam kaitannya dengan problematika keuangan daerah (APBD).

Persoalan ini adalah persoalan yang sangat menentukan dalam perkembangan investasi daerah, terutama bilamana investasi tersebut berkaitan dengan struktur anggaran pemerintah daerah, pengelolaannya, serta pertanggungjawabannya. Penanaman modal di daerah juga berimplikasi pada bagaimana interaksi hukum otonomi daerah dengan hukum investasi itu sendiri di Indonesia secara umum.

Provinsi Papua sendiri memiliki potensi Sumberdaya Alam yang sangat besar dari provinsi lainnya di Indonesia yang sampai saat ini belum dikelola dengan baik untuk kesejahteraan mayarakat. Papua juga terkenal dengaan sebutan "raksasa yang sedang tidur" yang mengandung kekayaan SDA yang baru kita mengetahui sedikit, dan dari sedikit itu kita baru mampu mengelola sedikit pula. Salah satu upaya yang dapat dilakukan oleh pemerintah untuk mempercepat pembangunan ekonomi nasional adalah melalui peningkatan investasi.

Dimana sasaran investasi disamping untuk memperbesar volume pembangunan secara nasional, juga untuk pengembangan sumber daya manusia serta pengelolaan sumberdaya alam yang tersedia saat ini diharapkan mampu meningkatkan taraf hidup dan kesejahteraan masyarakat.

Keberadaan investasi di Provinsi Papua saat ini selain dapat memberikan keuntungan bagi Investor, juga diharapkan dapat terjadi transformasi teknologi dan kemampuan manajerial yang dapat membangun jiwa enterpreneurship kepada masyarakat, sehingga pada saat dan dalam waktu tertentu masyarakat Papua secara umum dapat mengelola sumber dayanya secara mandiri dan berkelanjutan pada generasi selanjutnya. 
Sehingga untuk mengatasi permasalahan ini maka perlu sekali untuk mendistribusikan penyebaran investasi secara merata ke setiap sektor dan wilayah di Provinsi Papua, yang dapat berdampak terhadap pemerataan pembangunan ekonomi serta mewujudkan Papua Bangkit, Mandiri dan Sejahtera.

Maksud dari penelitian ini adalah memberi gambaran arah kebijakan investasi di Provinsi Papua dalam kaitannya untuk meningkatkan pertumbuhan ekonomi baik itu secara sektoral maupun kewilayahan. Sedangkan tujuannya adalah : 1) Mengukur dan menganalisis Capital Output Ratio dan Incremental Capital Output Ratio sebagai dasar untuk menetapkan arah kebijakan investasi secara sektoral dan kewilayahan di Provinsi Papua; 2) Mengestimasi kebutuhan investasi secara sektoral dan kewilayahan berdasarkan target pertumbuhan ekonomi tahun 2018; 3) Menganalisis faktor-faktor daya saing investasi dalam upaya meningkatkan dan mengembangkan investasi di sektor-sektor/ komoditas unggulan Provinsi Papua sebagaimana yang ditetapkan dalam RPJMD Provinsi Papua Tahun 2013-2018; dan 4) Menetapkan strategi kebijakan dan program pengembangan investasi sektoral dan kewilayahan yang dapat mempercepat pencapaian pertumbuhan ekonomi sesuai target pertumbuhan tahun 2018.

\section{METODOLOGI}

\section{Keterkaitan investasi dengan Pertumbuhan Ekonomi}

Dalam pengembangan teori investasi, salah satu teori investasi yang berkaitan dengan pertumbuhan ekonomi adalah model pertumbuhan HarrodDomar. Dimana inti dari model pertumbuhan ini adalah hubungan jangka pendek antara peningkatan investasi dan pertumbuhan ekonomi. Model ini mempunyai dua variabel fundamental, yaitu pembentukan modal tetap (investasi) serta ICOR (Incremental Capital Output Ratio) [Tambunan, 2001].

Beberapa penulis mengungkapkan bahwa nilai ICOR merupakan indikator untuk mengukur sejauh mana efisiensi dari suatu investasi di suatu 
wilayah (Saleh, 2014, Ambarita, 2012; Ilham, 2013;). Nilai ICOR sendiri dihitung sebagai rasio investasi terhadap PDB atau PDRB (Sukirno, 2004), dimana semakin rendah angka ICOR, menunjukkan bahwa investasi yang dilakukan semakin efisien (Jhingan, 2003). Nilai ICOR juga dapat dimanfaatkan untuk mengarahkan kebijakan yang harus ditempuh oleh pemerintah dalam rangka peningkatan efisiensi dalam pembangunan (Sadeghi et al., 2014). Oleh karenanya, melakukan klasifikasi kabupaten/kota sesuai dengan karakteristik nilai ICOR akan membantu upaya peningkatan kinerja dan efisiensi pembangunan pertanian.

Berdasarkan nilai ICOR yang dimilikinya setiap kabupaten/kota dapat menyusun kebijakan arah investasi apakah harus padat modal (capital intensive) ataukah tidak (non-capital intensive). Di samping itu, berdasarkan nilai ICOR yang dihasilkan akan diperoleh gambaran mengenai pendekatan pembangunan yang harus dilaksanakan, yaitu apakah dengan pendekatan sektoral secara utuh yang mencerminkan kewilayahan, pendekatan subsektor atau komoditas dan upaya-upaya apa yang harus dilakukan berkaitan dengan hal tersebut.

Secara matematis persamaan model pertumbuhan Harrod-Domar adalah sebagai berikut.

$$
\mathrm{S}=\mathrm{s} . \mathrm{Y}
$$

Tabungan (S) terdiri atas tabungan masyarakat, perusahaan, dan pemerintah yang merupakan suatu proporsi (s) dari total output atau pendapatan $(\mathrm{Y})$.

$$
\mathrm{I}=\Delta \mathrm{K}
$$

Investasi (I) merupakan perubahan stok modal (K). Stok modal mempunyai hubungan langsung dengan total output $(\mathrm{Y})$, seperti yang ditunjukkan oleh COR (capital output ratio) atau $\mathrm{k}$.

$$
\frac{K}{Y}=k \text { atau } \Delta \mathrm{K}=\mathrm{k} . \Delta \mathrm{Y}
$$

Dalam ekonomi yang seimbang (salah satu asumsi penting dari model HarrodDomar):

$$
\mathrm{S}=\mathrm{I} \text { maka didapat: } \mathrm{s} . \mathrm{Y}=\mathrm{k} . \Delta \mathrm{Y}
$$


Akhirnya pertumbuhan ekonomi $(\Delta \mathrm{Y} / \mathrm{Y})$ yang merupakan persentase perubahan GNP ditentukan secara bersama oleh rasio tabungan (s) dan rasio modal atau output nasional $(\mathrm{COR}=\mathrm{k})$.

$$
\Delta \mathrm{Y} / \mathrm{Y}=s / k
$$

Persamaan tersebut menyatakan bahwa tingkat pertumbuhan pendapatan ditentukan bersama-sama oleh rasio tabungan nasional, dan rasio modal (output nasional). Lebih khusus lagi, persamaan tersebut menyatakan bahwa tingkat pertumbuhan berkaitan dengan rasio tabungan, yakni lebih banyak bagian GNP yang ditabung dan diinvestasikan maka akan lebih besar lagi pertumbuhan GNP tersebut, dan sebaliknya berpengaruh secara negatif terhadap nisbah modal output suatu perekonomian (yakni, lebih besar k, lebih kecil pertumbuhan GNP). Singkatnya, agar bisa tumbuh maka perekonomian harus menabung dan menginvestasikan sebagian dari GNP-nya, karena dengan lebih banyak yang dapat ditabung dan kemudian diinvestasikan, maka akan lebih cepat lagi perekonomian itu tumbuh.

Meskipun demikian tingkat pertumbuhan yang dapat dijangkau pada setiap tingkat tabungan dan investasi tergantung pada produktivitas investasi tersebut [Hadi, 2003]. Sehingga bisa dikatakan bahwa investasi memiliki peran yang sangat penting dalam suatu perekonomian. Pentingnya investasi ini dapat ditinjau dari dua aspek. Pertama, karena investasi merupakan komponen yang besar dan volatile dari pengeluaran, investasi sering merujuk kepada perubahan dalam permintaan agregat sehingga mempengaruhi siklus bisnis.

Kedua, investasi mengacu pada akumulasi modal. Dengan menambah persediaan bangunanbangunan dan peralatan, akan meningkatkan output potensial dan akan mendorong pertumbuhan ekonomi jangka panjang. Dengan demikian investasi memiliki dua peran, yaitu mempengaruhi output jangka pendek melalui pengaruhnya terhadap permintaan agregat dan mempengaruhi pertumbuhan output jangka panjang melalui pengaruhnya terhadap pembentukan modal pada output potensial dan penawaran agregat (Samuelson dan Nordhaus, 2001). 
Akumulasi modal dalam perekonomian dapat terjadi apabila sebagian dari pendapatan ditabung dan diinvestasikan kembali, dengan tujuan untuk memperbesar output dan pendapatan di kemudian hari. Pengadaan pabrik baru, mesin-mesin, peralatan dan bahan baku meningkatkan stok modal secara fisik suatu negara (yakni, nilai riil "netto" atas seluruh barang modal produktif secara fisik) dan hal itu jelas memungkinkan akan terjadinya peningkatan output di masa mendatang.

Dimana investasi produktif yang bersifat langsung tersebut harus dilengkapi dengan berbagai investasi penunjang yang disebut dengan investasi infrastruktur ekonomi dan sosial. Contohnya adalah pembangunan jalan raya, penyediaan listrik, persediaan air bersih dan perbaikan sanitasi, yang kesemuanya itu mutlak dibutuhkan dalam rangka menunjang dan mengintegrasikan segenap aktivitas ekonomi produktif.

Investasi dalam pembinaan sumber daya manusia juga meningkatkan kualitas modal manusia, sehingga pada akhirnya akan membawa dampak positif yang sama terhadap angka produksi, bahkan akan lebih besar lagi mengingat terus bertambahnya jumlah manusia (Todaro, 2004).

\section{Ruang Lingkup, Obyek dan Tahapan Kajian}

Kegiatan kajian ini melingkupi dua hal yaitu ruang lingkup wilayah dan ruang lingkup materi. Ruang lingkup wilayah adalah Pemerintah Daerah Provinsi Papua serta instansi pendudukung lainnya di lingkungan Pemerintah Provinsi, kabupaten/kota di Papua. Sedangkan ruang lingkup kajian materi meliputi: analisis ekonomi makro pada tingkat regional kabupaten/kota di Provinsi Papua, dan teori serta kajian tentang pertumbuhan ekonomi regional. Selain itu juga, kegiatan ini akan membahas tentang investasi di kabupaten/kota di wilayah Papua dan kompleksitas yang melingkupi permasalahan investasi serta solusi altenatif penyelesaian masalah tersebut beserta kajian mengenai kebijakan investasi. 


\section{Jenis dan Sumber Data}

Studi ini menggunakan dua pendekatan yaitu kuantitatif dan kualitatif. Pendekatan kuantitatif yaitu meliputi data sekunder yaitu data yang diperoleh secara tidak langsung dari objek penelitian. Data sekunder merupakan data yang tidak diperoleh dari sumbernya langsung, melainkan sudah dikumpulkan oleh pihak lain.

Metode pengumpulan data diperoleh dengan dilkukannya teknik dokumentasi, yaitu pengumpulan data baku yang diperoleh pada Instansi atau Organisasi yang ada, baik pemerintah maupun swasta (Muslimin, 2002). Sumber data sekunder berasal dari beberapa instansi yang berwenang dalam pengeluaran data yaitu APBD, Badan Perencanaan Pembangunan Papua, kabupaten/kota, Badan Pusat Statistik dan intansi-intansi terkait serta berbagai hasil penelitian yang berkaitan dengan kajian ini.

Sedangkan data primer diperoleh langsung melalui depth interview atau wawancara secara mendalam oleh peneliti. Dalam melakukan wawancara tersebut peneliti akan menggunakan pedoman interview yang telah disusun sebelumnya sehingga akan menghasilkan interview yang terarah sesuai dengan tujuan penelitian.

\section{Metode Analisis}

Beberapa metode kuantitatif yang digunakan merupakan model-model perencanaan pembangunan wilayah yang bersifat makroregional seperti model pertumbuhan, COR dan ICOR. Data-data yang dibutuhkan diliput dengan metode dokumentasi yang bersumber dari instansi yang berkompeten.

Secara teoritis hubungan ICOR dengan pertumbuhan ekonomi dikembangkan pertama kali oleh R. F. Harrod dan Evsey Domar. Pengkajian mengenai ICOR menjadi sangat menarik karena ICOR dapat merefleksikan besarnya produktifitas kapital yang pada akhirnya menyangkut besarnya pertumbuhan ekonomi yang bisa dicapai. 


\section{ICOR Tahunan}

Perkiraan ICOR tahunan dilakukan berdasarkan data time series tahunan yang dapat dipisah berdasarkan gestation period (tenggang waktu) sebagai berikut.

\section{a. ICOR Tanpa Tenggang Waktu}

Bila investasi yang dilakukan pada tahun ke $t$ diasumsikan akan menghasilkan tambahan pendapatan (output) pada tahun ke $t$ juga, maka perkiraan ICOR yang diperoleh melalui pendekatan ini merupakan ICOR tanpa tenggang waktu yang dapat dihitung dengan rumus :

$$
k_{t}=\frac{I_{i t}}{\Delta Y_{i t}}=\frac{\frac{I_{i t}}{Y_{i t-1}} x 100}{g_{i t}}
$$

dimana :

$k_{\text {it }} \quad$ adalah ICOR pada tahun ke $t$ untuk aktifitas $i$

$l_{i t} \quad$ adalah investasi pada tahun ke $t$ untuk aktifitas $i$

$Y_{i t-1}$ adalah pendapatan regional pada tahun ke $t-1$ untuk aktifitas $i$

$g_{i t} \quad$ adalah laju pertumbuhan aktifitas $i$ pada tahun ke $t$

\section{b. ICOR Tenggang Waktu Satu Tahun}

Perkiraan ICOR dengan tenggang waktu satu tahun mengandung pengertian bahwa investasi yang dilakukan pada tahun $t-1$ baru akan memberikan tambahan hasil pada tahun $t$. Perkiraan ICOR dengan tenggang waktu satu tahun dapat dihitung dengan rumus :

$$
k_{t}=\frac{I_{i t-1}}{\Delta Y_{i t}}=\frac{\frac{I_{i t-1}}{Y_{i t-1}} x 100}{g_{i t}}
$$

dimana :

$k_{i t} \quad$ adalah ICOR pada tahun ke $t$ untuk aktifitas $i$

$l_{i-1}$ adalah investasi pada tahun ke $t-1$ untuk aktifitas $i$

$Y_{i t-1}$ adalah pendapatan regional pada tahun ke $t-1$ untuk aktifitas $i$

$g_{\text {it }}$ adalah laju pertumbuhan aktifitas $i$ pada tahun ke $t$ 


\section{c. ICOR Tenggang Waktu Lebih dari Satu Tahun}

Dalam beberapa aktifitas tertentu, jangka waktu antara investasi dan tambahan hasil yang diperoleh sebagai akibat investasi tersebut dapat lebih dari satu tahun. Bila sekiranya jangka waktu investasi tahun ke $t-2$ baru akan memberikan tambahan pendapatan regional pada tahun $t$ maka perhitungan ICOR dilakukan dengan cara :

$$
k_{t}=\frac{I_{i t-2}}{\Delta Y_{i t}}=\frac{\frac{I_{i t-2}}{Y_{i t-1}} x 100}{g_{i t}}
$$

sedangkan bila tambahan hasil baru diperoleh tiga tahun kemudian maka ICOR dihitung dengan formulasi :

$$
k_{t}=\frac{I_{i t-3}}{\Delta Y_{i t}}=\frac{\frac{I_{i t-3}}{Y_{i t-1}} x 100}{g_{i t}}
$$

dimana :

$k_{i t} \quad$ adalah ICOR pada tahun ke $t$ untuk aktifitas $i$

$l_{i-2}$ adalah investasi pada tahun ke $t-2$ untuk aktifitas $i$

$l_{i t-3} \quad$ adalah investasi pada tahun ke $t-2$ untuk aktifitas $i$

$Y_{i t-1} \quad$ adalah pendapatan regional pada tahun ke $t-1$ untuk aktifitas $i$

$g_{i t} \quad$ adalah laju pertumbuhan aktifitas $i$ pada tahun ke $t$

\section{Perkiraan ICOR Rata-rata}

Perkiraan ICOR rata-rata kurang tepat bila dilakukan berdasarkan ratarata ICOR per tahun, karena bisa terjadi pembiasan angka yang mungkin saja terjadi pada tahun-tahun tertentu. Untuk mengatasi hal tersebut, perhitungan ICOR rata-rata sebaiknya dilakukan berdasarkan perkembangan investasi dan tambahan hasil secara kumulatif dalam jangka waktu tertentu. Sebagaimana halnya ICOR tahunan, perhitungan ICOR ratarata juga dapat dibedakan berdasarkan tenggang waktu. Namun secara umum rumus ICOR rata-rata ini adalah sebagai berikut: 


$$
\bar{k}_{t}=\frac{\sum_{t=0}^{t-n} I_{i t-n}}{\Delta Y_{i t}}
$$

dimana :

$$
\begin{array}{ll}
\bar{k} & \text { adalah ICOR rata-rata } \\
l & \text { adalah investasi } \\
\Delta Y & \text { adalah tambahan hasil (pendapatan regional) } \\
i & \text { adalah aktifitas ke } i \\
t & \text { adalah tahun ke } t \\
h & \text { adalah tenggang waktu yang digunakan dimana } h \geq 1
\end{array}
$$

\section{Perkiraan Tenggang Waktu Pengembalian Investasi}

Salah satu pekerjaan yang paling penting dan harus dilakukan secermat mungkin dalam menghitung ICOR adalah menetapkan tenggang waktu untuk kegiatan investasi tertentu. Beberapa kegiatan investasi memang sangat mudah ditentukan tenggang waktu pengembalian hasilnya (pendapatan regional), dan umumnya usaha pertanian tidak memiliki tenggang waktu pengembalian investasi, artinya apa yang diinvestasikan tahun sekarang hasilnya dapat dilihat pada tahun sekarang juga. Contohnya padi, sayur mayur, buah-buahan, perikanan, dan lain-lain. Tetapi untuk sebagian komoditi pertanian ada juga yang memiliki tenggang waktu investasi satu atau dua tahun lebih seperti kelapa sawit, coklat, karet, dan sebagainya. Sedangkan untuk industri, pertambangan dan sektor-sektor jasa lainnya memiliki tenggang waktu yang sangat bervariasi, ada yang satu, dua, bahkan tiga tahun.

\section{Perhitungan Marginal Capital Output Ratio}

Perkiraan ICOR rata-rata sebagaimana yang disajikan pada persamaan [6] dikategorikan sebagai perkiraan ICOR discrete yang menganggap bahwa perubahan hasil yang diperoleh diukur dengan unit 
perubahan yang cukup besar. Akibatnya ICOR yang diperoleh banyak melompat-lompat setiap waktu tertentu. Guna mengatasi kondisi ini telah disediakan perhitungan ICOR yang bersifat continous yang bisa mengukur perubahan secara berkesinambungan dan stabil. Dalam pengertian continous ini ICOR biasa disebut dengan istilah MCOR (marginal capital output ratio) yang dibangun melalui persamaan :

$\log \mathrm{Y}_{\mathrm{it}}=a+b \log \mathrm{I}_{\mathrm{it}-\mathrm{n}}+\mathrm{e}_{\mathrm{it}}$

Berdasarkan persamaan [7] kemudian dihitung MCOR dengan rumus:

$$
\bar{k}_{i t}=\frac{1}{b} \frac{\sum_{t=0}^{t-n} I_{i t-n}}{Y_{t}}
$$

dimana $k$ adalah MCOR, $Y$ adalah pendapatan regional, I adalah investasi regional, $\mathrm{t}$ adalah tahun ke $\mathrm{t}$, dan $\mathrm{n}$ adalah tenggang waktu yang digunakan. Saat ini dianggap perhitungan MCOR lebih teliti dibandingkan ICOR tahunan ataupun rata-rata.

\section{c). Perkiraan Kebutuhan Investasi}

Penetapan sasaran laju pertumbuhan ekonomi mengandung implikasi yang cukup besar di dalam memperkirakan kebutuhan investasi yang diperlukan untuk mencapai sasaran pertumbuhan ekonomi tersebut. Dalam konteks ini, semakin tinggi sasaran laju pertumbuhan ekonomi yang ingin dicapai, maka semakin besar pula kebutuhan investasi di masa mendatang, begitu sebaliknya.

Seandainya telah diketahui besarnya ICOR (tahunan atau rata-rata) dan telah ditetapkan sasaran pertumbuhan ekonomi wilayah, maka investasi yang dibutuhkan untuk menghasilkan target pertumbuhan ekonomi tersebut dihitung dengan persamaan:

$$
\hat{I}=k \Delta \mathrm{Y}
$$

dimana $\hat{I}$ adalah perkiraan investasi yang dibutuhkan, $k$ adalah ICOR dan $\Delta \mathrm{Y}$ besarnya pertambahan hasil. 
Perkiraan kebutuhan investasi yang dipaparkan dalam persamaan [9] juga dihitung berdasarkan tenggang waktu, hal ini disesuaikan tenggang waktu ICOR yang digunakan dalam persamaan tersebut. Misalkan ICOR yang dipakai memiliki tenggang waktu satu tahun, maka perkiraan investasi yang dihitung juga memiliki tenggang waktu satu tahun. Demikian bila tenggang waktu ICOR adalah dua tahun, berarti perkiraan investasi juga berdasarkan tenggang waktu dua tahun.

\section{ESTIMASI TARGET PERTUMBUHAN INVESTASI REGIONAL}

\section{A. Perkembangan Penanaman Modal}

Pertumbuhan proyek investasi di Provinsi Papua baik itu PMDN maupun PMA selama periode 2007-2013 tampak lebih cepat dibandingkan dengan periode 2013-2016. Namun, untuk realisasi investasi tampak pertumbuhan investasi selama periode 2013-2016 masih cukup lebih baik dibandingkan periode sebelumnya.

Tabel 1

Perkembangan PMDN di Provinsi Papua, 2016

\begin{tabular}{|c|c|r|r|}
\hline \multirow{2}{*}{ Tahun } & \multirow{2}{*}{ Proyek } & \multicolumn{2}{|c|}{ Nilai Investasi (juta rp) } \\
\cline { 3 - 4 } & & Rencana & Realisasi \\
\hline 2007 & 32 & $37,493,882$ & $1,456,388$ \\
\hline 2008 & 28 & $57,395,187$ & $1,469,913$ \\
\hline 2009 & 29 & $63,020,041$ & $1,811,052$ \\
\hline 2010 & 29 & $62,320,259$ & $2,401,060$ \\
\hline 2011 & 30 & $62,331,309$ & $3,263,477$ \\
\hline 2012 & 42 & $138,398,402$ & $8,353,523$ \\
\hline 2013 & 65 & $167,197,544$ & $10,679,551$ \\
\hline 2014 & 78 & $173,144,314$ & $19,137,376$ \\
\hline 2015 & 78 & $172,474,114$ & $46,650,707$ \\
\hline 2016 & 87 & $184,118,220$ & $59,833,954$ \\
\hline \multicolumn{3}{|l}{} & 39.38 \\
\hline Rata-Rata Pertumbuhan (\%) & \\
\hline $2007-2013$ & 12.54 & \multicolumn{3}{|c}{} \\
\hline $2013-2016$ & 10.21 &
\end{tabular}

Sumber: Badan Penanaman Modal dan Pelayanan Terpadu Satu Pintu Provinsi Papua, 2017

Rata-rata pertumbuhan investasi di Provinsi Papua sepanjang tahun 2013-2016 tercatat bisa mencapai 77,61\% per tahun untuk PMDN, dan 56,03\% per tahun untuk PMA. Dimana di tahun 2015 terjadi Ionjakan 
investasi PMDN dan PMA yang begitu tinggi jika dibandingkan dengan tahuntahun sebelumnya.

Tabel 2.

Perkembangan PMA di Provinsi Papua, 2016

\begin{tabular}{|c|c|c|c|}
\hline \multirow{2}{*}{ Tahun } & \multirow{2}{*}{ Proyek } & \multicolumn{2}{|c|}{ Nilai Investasi (juta Rp) } \\
\hline & & Rencana & Realisasi \\
\hline 2007 & 54 & $5,387,016$ & $6,525,783$ \\
\hline 2008 & 65 & $5,071,086$ & $6,529,785$ \\
\hline 2009 & 74 & $5,161,341$ & $6,572,907$ \\
\hline 2010 & 79 & $5,316,816$ & $8,251,496$ \\
\hline 2011 & 87 & $5,440,764$ & $8,596,401$ \\
\hline 2012 & 95 & $7,008,568$ & $11,120,015$ \\
\hline 2013 & 103 & $9,358,965$ & $18,545,113$ \\
\hline 2014 & 108 & $10,908,658$ & $29,563,670$ \\
\hline 2015 & 122 & $446,607,858$ & $47,393,679$ \\
\hline 2016 & 126 & $445,525,265$ & $70,442,220$ \\
\hline \multicolumn{4}{|c|}{ Rata-Rata Pertumbuhan (\%) } \\
\hline $2007-2013$ & 11.36 & & 19.01 \\
\hline 2013-2015 & 6.95 & & 56.03 \\
\hline
\end{tabular}

Sumber: Badan Penanaman Modal dan Pelayanan Terpadu Satu Pintu Provinsi Papua, 2017

\section{B. Rasio Capaian Realisasi Penanaman Modal}

Rasio pencapaian realisasi investasi dengan fasilitas PMDN terlihat sangat rendah bila dibandingkan dengan PMA. Meskipun demikian ada kecenderungan rasio capaian investasi PMDN peningkatannya lebih signifikan dibandingkan PMA. Dimana pada tahun 2015, realisasi investasi pada PMA mengalami penurunan yang sangat curam dari $271,01 \%$ di tahun 2014 menjadi $10,61 \%$. Kondisi ini pada akhirnya membuat capaian total investasi di Provinsi Papua juga turun hingga mencapai 15,19\%. 
Gambar 1.

Rasio Capaian Realisasi Penanaman Modal Papua, 2016
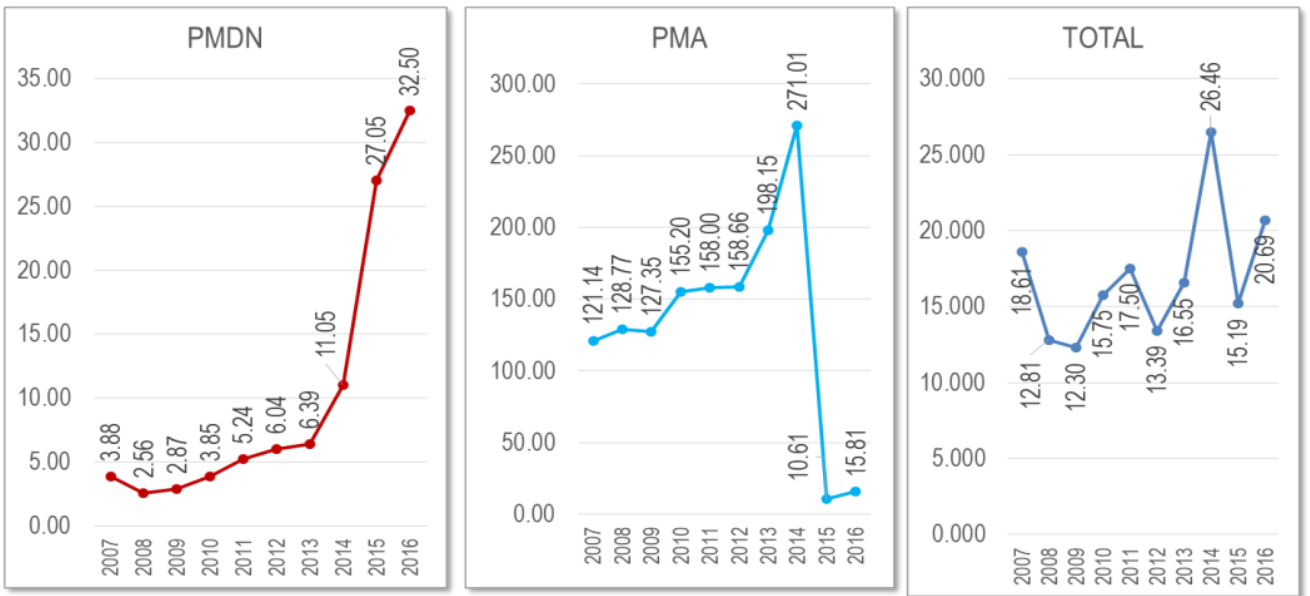

Sumber: Badan Penanaman Modal dan Pelayanan Terpadu Satu Pintu Provinsi Papua, 2017 (data diolah)

\section{Profil Investasi Secara Sektoral Tahun 2016}

Kondisi investasi saat ini memiliki kecenderungan pihak asing yang lebih banyak berinvestasi di Provinsi Papua bila dibandingkan dengan investor dalam negeri, dimana jika dilihat secara sektoral, pihak asing lebih dominan berinvestasi di sektor pertambangan dan jasa pertambangan. Sedangkan para investor dalam negeri lebih menyukai sektor perkebunan.

Tabel 3.

Perkembangan Investasi Sektoral Provinsi Papua, 2016

\begin{tabular}{|c|c|c|c|c|c|c|c|c|c|}
\hline \multirow[b]{2}{*}{ No } & \multirow[b]{2}{*}{ Sektor } & \multicolumn{3}{|c|}{ Proyek } & \multicolumn{3}{|c|}{ Tenaga Kerja } & \multicolumn{2}{|c|}{ Nilai Investasi } \\
\hline & & $\begin{array}{l}\text { PMDN } \\
\text { (unit) }\end{array}$ & $\begin{array}{l}\text { PMA } \\
\text { (unit) }\end{array}$ & $\begin{array}{l}\text { Total } \\
\text { (unit) }\end{array}$ & $\begin{array}{l}\text { PMDN } \\
\text { (org) }\end{array}$ & $\begin{array}{l}\text { PMA } \\
\text { (org) }\end{array}$ & $\begin{array}{l}\text { Total } \\
\text { (org) }\end{array}$ & $\begin{array}{l}\text { PMDN } \\
\text { (rp juta) }\end{array}$ & $\begin{array}{c}\text { PMA } \\
\text { (US\$ ribu) }\end{array}$ \\
\hline 1. & PERKEBUNAN & 49 & 26 & 75 & 8,592 & 7,840 & 16,432 & $31,893,957$ & $12,527,259$ \\
\hline 2. & PERIKANAN & 0 & 4 & 4 & - & 7,083 & 7,083 & - & 522,129 \\
\hline 3. & PERTANIAN/PETERNAKAN & 9 & 5 & 14 & 38 & 19 & 57 & $10,338,314$ & 40,381 \\
\hline 4. & KEHUTANAN & 2 & 2 & 4 & 430 & 19 & 449 & $1,165,812$ & 702,315 \\
\hline 5. & PERTAMBANGAN & 4 & 12 & 16 & - & 33,142 & 33,142 & - & $14,753,095$ \\
\hline 6. & JASA PERTAMBANGAN & 1 & 32 & 33 & - & 1,881 & 1,881 & - & $9,516,124$ \\
\hline 7. & JASA PERHOTELAN /PARIWISATA & 1 & 4 & 5 & 121 & 292 & 413 & 18,585 & 239,459 \\
\hline 8. & JASA PERDAGANGAN & 0 & 8 & 8 & - & 1,096 & 1,096 & - & 325,595 \\
\hline 9. & JASA LAINNYA & 6 & 18 & 24 & 135 & 9,505 & 9,640 & 623,476 & $30,886,516$ \\
\hline 10. & INDUSTRI KAYU & 6 & 6 & 12 & 2,079 & 1,994 & 4,073 & $5,681,026$ & 525,816 \\
\hline 11. & INDUSTRI KIMIA & 1 & 2 & 3 & 28 & - & 28 & 2,000 & - \\
\hline 12. & INDUSTRI LAINNYA & 5 & 6 & 11 & 3,458 & 1,216 & 4,674 & $9,760,784$ & 340,129 \\
\hline & Total & 84 & 125 & 209 & 14,881 & 64,087 & 78,968 & $59,483,954$ & $70,378,818$ \\
\hline
\end{tabular}

Sumber: Badan Penanaman Modal dan Pelayanan Terpadu Satu Pintu Provinsi Papua, 2017 (data diolah) 
Secara keseluruhan terlihat peran PMA dalam menyerap lapangan kerja lebih besar dibandingkan PMDN. Tetapi jika diamati secara sektoral, kontribusi PMDN dalam penyerapan tenaga kerja di sektor perkebunan, industri kayu dan industri lainnya lebih dominan dibandingkan PMA. Untuk nilai investasi, dipastikan PMA lebih besar memberi sumbangan terhadap struktur investasi regional, terutama pada sektor pertambangan dan sektor jasa lainnya.

\section{Profil Investasi Secara Kewilayahan Tahun 2016}

Secara kewilayahan tampak ada ketimpangan distribusi penyebaran investasi di Provinsi Papua yang sangat tinggi. Terindikasi proyek-proyek PMA lebih dominan terkonsentrasi pada Kabupaten Jayapura dan Merauke. Sementara untuk PMDN dominan terkumpul di Kota Jayapura, Merauke, Mimika dam Nabire. Patut diapresiasi bahwa seluruh wilayah kabupaten/kota di Provinsi Papua telah diminati oleh para investor, meskipun beberapa diantaranya hanya ada 1 atau 2 proyek saja.

Jika diperhatikan dari rasio pencapaian investasi PMA di tahun 2016, dapat dikatakan yang paling tinggi capaiannya adalah di Kota Jayapura, Keerom, dan Sarmi, ketiganya bisa lebih dari 1000\%. Sehingga secara menyeluruh rasio capaian untuk PMA sebesar 530,30\%. Beda halnya dengan capaian realisasi PMDN, jauh dibawah yaitu $32,27 \%$. 
Tabel 4

Perkembangan Investasi Kewilayahan Papua, 2016

\begin{tabular}{|c|c|c|c|c|c|c|c|c|c|c|}
\hline \multirow[b]{2}{*}{ No. } & \multirow{2}{*}{ Kabupaten/Kota } & \multicolumn{3}{|c|}{ Proyek } & \multicolumn{3}{|c|}{ PMA } & \multicolumn{3}{|c|}{ PMDN } \\
\hline & & PMDN & PMA & Total & $\begin{array}{l}\text { Rencana } \\
\text { (US\$ ribu) }\end{array}$ & $\begin{array}{c}\text { Realisasi } \\
\text { (juta rp) }\end{array}$ & $\begin{array}{c}\text { Rasio Capaian } \\
(\%)\end{array}$ & $\begin{array}{l}\text { Rencana } \\
\text { (US\$ ribu) }\end{array}$ & $\begin{array}{c}\text { Realisasi } \\
\text { (juta rp) }\end{array}$ & $\begin{array}{c}\text { Rasio Capaian } \\
(\%)\end{array}$ \\
\hline 1. & Kota Jayapura & 11 & 2 & 13 & 416,750 & $9,667,243$ & $2,319.67$ & 684,700 & 500,000 & 73.02 \\
\hline 2. & Jayapura & 8 & 13 & 21 & 130,030 & 4,659 & 3.58 & $15,704,937$ & $14,631,748$ & 93.17 \\
\hline 3. & Keerom & 4 & 9 & 13 & 20,137 & 468,151 & $2,324.83$ & $1,912,299$ & $5,435,215$ & 284.22 \\
\hline 4. & Sarmi & 3 & 3 & 6 & 7,850 & 215,342 & $2,743.21$ & $4,297,000$ & 353,000 & 8.22 \\
\hline 5. & Mamberamo Raya & 1 & 2 & 3 & 255,750 & 340,000 & 132.94 & 485,404 & 7,659 & 1.58 \\
\hline 6. & Merauke & 21 & 20 & 41 & $2,531,850$ & $11,735,521$ & 463.52 & $109,672,864$ & $12,038,298$ & 10.98 \\
\hline 7. & Boven Digul & 7 & 6 & 13 & 954,400 & 429,084 & 44.96 & $1,441,065$ & $8,293,921$ & 575.54 \\
\hline 8. & Mappi & 0 & 7 & 7 & - & - & - & $20,358,826$ & 125,000 & 0.61 \\
\hline 9. & Mimika & 36 & 6 & 42 & $6,886,944$ & $44,786,011$ & 650.30 & $3,736,978$ & $7,323,650$ & 195.98 \\
\hline 10. & Waropen & 1 & 4 & 5 & 14,150 & - & - & $7,762,360$ & - & - \\
\hline 11. & Kepulauan Yapen & 0 & 1 & 1 & - & - & - & 290,430 & 291,610 & 100.41 \\
\hline 12. & Biak Numfor & 4 & 0 & 4 & 92,525 & 124,669 & 134.74 & - & - & - \\
\hline 13. & Paniai & 4 & 1 & 5 & $1,159,732$ & $1,082,826$ & 93.37 & $12,071,403$ & $9,318,041$ & 77.19 \\
\hline 14. & Nabire & 22 & 4 & 26 & 599,705 & $1,523,662$ & 254.07 & $1,246,200$ & $1,165,812$ & 93.55 \\
\hline 15. & Jayawijaya & 2 & 0 & 2 & 3,130 & 1,650 & 52.72 & - & - & - \\
\hline 16. & Lanny Jaya & 1 & 0 & 1 & 50,000 & - & - & - & - & - \\
\hline 17. & Pegunungan Bintang & 0 & 1 & 1 & - & - & - & 13,400 & - & - \\
\hline 18. & Asmat & 0 & 1 & 1 & - & - & - & 5,218 & - & - \\
\hline 19. & Yahukimo & 0 & 3 & 3 & - & - & - & $4,000,000$ & - & - \\
\hline 20. & Intan Jaya & 0 & 1 & 1 & - & - & - & 77,000 & & - \\
\hline & Jumlah & 125 & 84 & 209 & $13,122,953$ & $70,378,818$ & 536.30 & $183,760,084$ & $59,483,954$ & 32.37 \\
\hline
\end{tabular}

Sumber: Badan Penanaman Modal dan Pelayanan Terpadu Satu Pintu Provinsi Papua, 2017 (data diolah)

\section{E. Keterkaitan ICOR dengan Efisiensi}

ICOR adalah angka yang menunjukkan besarnya penambahan investasi untuk menghasilkan tambahan output. Rasio ini digunakan untuk menghitung seberapa efisien pembangunan ekonomi di suatu negara/wilayah. Jika angka ICOR tinggi, pembangunan tidak efisien, yang salah satunya disebabkan adanya kebocoran anggaran.

Nilai ICOR yang efisien, secara umum berada di kisaran 3\% - 4\%, yang artinya untuk meningkatkan Produk Domestik Bruto (PDB) 1\% di suatu negara, dibutuhkan tambahan investasi hingga 3\% - 4\%. Nilai ICOR yang semakin kecil, mengindikasikan terjadinya efisiensi dalam proses investasi, sebaliknya nilai ICOR yang membesar menggambarkan tingginya in-efisiensi investasi.

Berdasarkan perhitungan yang dilakukan oleh Komite Ekonomi Nasional (KEN) dan juga Badan Pusat Statistik (BPS), ICOR Indonesia dari tahun 2004-2008 sebetulnya sudah berada di bawah kisaran 4\%. Tahun 2004 nilai ICOR Indonesia 4,4\%, 2005 sekitar 4,5\%, 2006 sekitar 4\%, 2007 
sekitar 3,7\% dan 2008 sekitar4,2\%. Namun di tahun 2013-2015 ICOR Indonesia naik kembali dari 4,5\% di tahun 2013 menjadi 6,8\% di tahun 2015 (Institute for Development of Economy \& Finance, 2016). Secara harfiah terminologi ICOR sebesar 6,8 tersebut mengindikasikan untuk meningkatkan PDB sebesar $1 \%$ membutuhkan peningkatan investasi sebanyak $6 \%$ dari PDB. Ini berarti di tahun 2015 telah terjadi kebocoran ekonomi mencapai $41,12 \%$ (dari nilai moderat $3 \%-4 \%$ ).

Paling tidak ada tiga faktor yang menyebabkan inefisiensi dalam investasi yang dilakukan pemerintah yang menyebabkan ICOR meningkat (Edward, 2017). Pertama, tidak efisiennya pembangunan ekonomi yang dijalankan. Kedua, adanya unsur pelunasan hutang luar negeri yang tinggi dan didominas dengan valuta asing. Ketiga, adanya mark up dan korupsi dalam proses pembangunan.

Sedangkan menurut Prof. Sumitro, ada beberapa faktor yang menyebabkan rendahnya efisiensi dari investasi. Pertama, terdapat kelemahan teknis dalam perencanaan, penyelenggaran, dan perawatan proyek-proyek investasi. Kedua, investasi infrastruktur yang bersifat slow yielding dan low yielding. Ketiga, iklim institusional yang kurang baik, yaitu penyimpangan dan penyelewengan atas investasi yang direncanakan.

\section{a) ICOR Regional Provinsi Papua}

Jika asumsi ICOR $2016=3,38$ tidak berubah hingga 2018, maka untuk menciptakan pertumbuhan ekonomi sebesar $8 \%$ seperti yang ditargetkan dalam RPJMD 2013-2018 dibutuhkan kenaikan investasi sebesar $\Delta \% \mathrm{l}=3,38 \% \times 8 \%=27,04 \%$ dari tahun 2017. Padahal rata-rata kenaikan investasi (PMTB) selama periode 2012-2016 hanya sebesar 6,94\% per tahun. 
Gambar 2.

Perkembangan COR, ICOR dan Pertumbuhan Investasi Papua, 2016

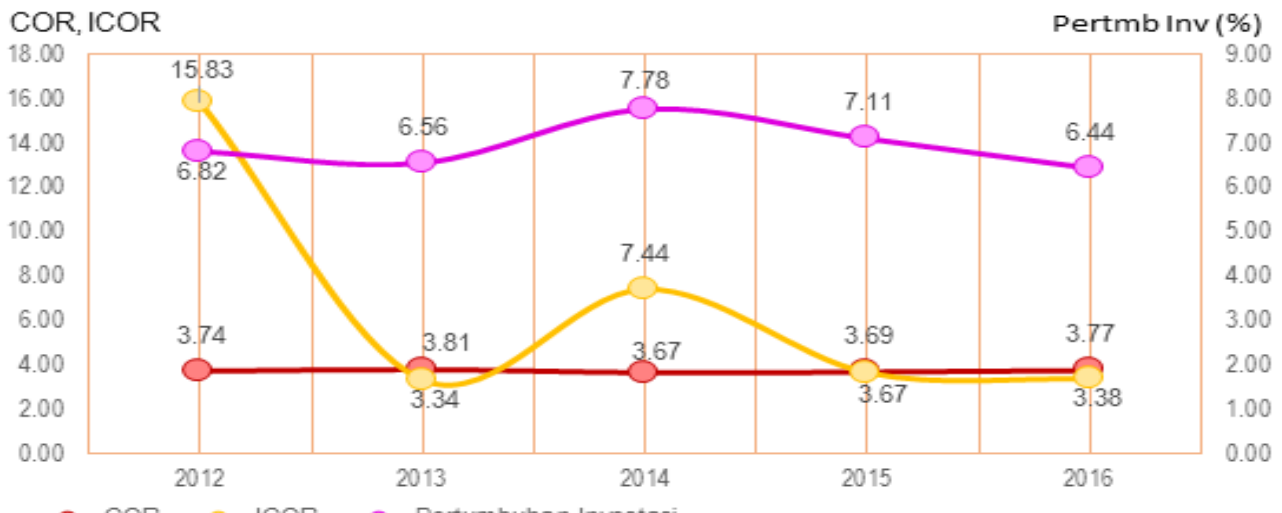

Sumber: BPS Provinsi Papua, 2017 (data diolah)

Berikut ini disajikan hasil perhitungan ICOR menggunakan data makro (PDRB Kabupaten/Kota) yang menghasilkan ICOR spasial sebagai berikut :

Tabel 5.

ICOR Spasial, 2016

\begin{tabular}{|c|c|c|c|c|c|c|c|c|}
\hline \multirow{2}{*}{ Kabupaten } & \multicolumn{3}{|c|}{ Rata-Rata Nilai dan Produktifitas } & \multicolumn{3}{|c|}{ Rata-Rata Pertumbuhan dan Elastisitas } & \multicolumn{2}{|c|}{ ICOR } \\
\hline & РMTB & PDRB & $\begin{array}{c}\text { Produktifitas } \\
\text { Modal }\end{array}$ & $\begin{array}{c}\text { Pertumbuhan } \\
\text { PMTB }\end{array}$ & $\begin{array}{l}\text { Pertumbuhan } \\
\text { PDRB }\end{array}$ & $\begin{array}{c}\text { Elastisitas } \\
\text { Modal }\end{array}$ & Persentase & Kriteria \\
\hline Merauke & $2,158,327.61$ & $9,093,297.77$ & 4.21 & 13.86 & 14.61 & 1.05 & 1.87 & Efisien \\
\hline Jayawijaya & $1,636,752.22$ & $4,791,376.76$ & 2.93 & 14.13 & 14.60 & 1.03 & 2.70 & Efisien \\
\hline Jayapura & $1,965,041.69$ & $8,607,504.87$ & 4.38 & 11.92 & 17.37 & 1.46 & 1.55 & Efisien \\
\hline Nabire & $1,499,293.25$ & $6,815,639.68$ & 4.55 & 13.05 & 14.06 & 1.08 & 1.80 & Efisien \\
\hline Kepulauan Yapen & $636,810.97$ & $2,705,521.63$ & 4.25 & 12.00 & 12.05 & 1.00 & 2.21 & Efisien \\
\hline Biak Numfor & $816,963.40$ & $4,000,756.33$ & 4.90 & 13.60 & 13.49 & 0.99 & 1.74 & Efisien \\
\hline Paniai & $1,007,984.05$ & $2,595,586.30$ & 2.58 & 12.32 & 14.21 & 1.15 & 3.16 & Efisien \\
\hline Puncak Jaya & $376,447.97$ & $932,194.11$ & 2.48 & 12.24 & 9.81 & 0.80 & 4.81 & -16.82 \\
\hline Mimika & $11,869,102.93$ & $55,200,433.79$ & 4.65 & 13.20 & 9.16 & 0.69 & 0.61 & Efisien \\
\hline Boven Digoel & $874,907.25$ & $3,226,672.73$ & 3.69 & 12.57 & 10.71 & 0.85 & 2.85 & Efisien \\
\hline Mappi & $819,262.72$ & $1,721,562.96$ & 2.10 & 13.61 & 12.83 & 0.94 & 4.33 & -7.54 \\
\hline Asmat & $730,031.62$ & $1,480,600.16$ & 2.03 & 12.75 & 11.91 & 0.93 & 4.72 & -15.23 \\
\hline Yahukimo & $796,160.97$ & $1,515,078.08$ & 1.90 & 11.97 & 12.76 & 1.07 & 4.73 & -15.37 \\
\hline Peg. Bintang & $560,241.50$ & $1,208,263.71$ & 2.16 & 12.80 & 10.40 & 0.81 & 5.13 & -21.99 \\
\hline Tolikara & $475,578.27$ & $1,021,486.32$ & 2.15 & 13.67 & 11.16 & 0.82 & 4.72 & -15.24 \\
\hline Sarmi & $789,175.59$ & $1,637,326.66$ & 2.07 & 13.40 & 12.79 & 0.95 & 4.32 & -7.48 \\
\hline Keerom & $946,350.11$ & $1,878,002.03$ & 1.98 & 11.54 & 13.10 & 1.13 & 4.44 & -9.85 \\
\hline Waropen & $581,187.94$ & $1,258,153.42$ & 2.16 & 12.68 & 16.03 & 1.26 & 3.35 & Efisien \\
\hline Supiori & $372,594.00$ & $702,618.48$ & 1.89 & 12.37 & 9.03 & 0.73 & 6.65 & -39.82 \\
\hline Mamberamo Raya & $468,905.10$ & $899,896.08$ & 1.92 & 13.85 & 16.93 & 1.22 & 3.68 & Efisien \\
\hline Nduga & $341,097.25$ & $709,197.38$ & 2.08 & 14.35 & 14.88 & 1.04 & 3.75 & Efisien \\
\hline Lanny Jaya & $499,462.45$ & $1,100,687.16$ & 2.20 & 13.35 & 13.15 & 0.99 & 3.93 & Efisien \\
\hline Mambe. Tengah & $358,387.43$ & $712,394.54$ & 1.99 & 14.48 & 14.26 & 0.99 & 4.11 & -2.70 \\
\hline Yalimo & $345,877.87$ & $701,388.76$ & 2.03 & 12.94 & 16.35 & 1.26 & 3.52 & Efisien \\
\hline Puncak & $400,584.04$ & $789,533.07$ & 1.97 & 13.15 & 17.14 & 1.30 & 3.49 & Efisien \\
\hline Dogiyai & $337,377.62$ & $801,541.80$ & 2.38 & 12.66 & 14.45 & 1.14 & 3.39 & Efisien \\
\hline Intan Jaya & $329,089.21$ & $762,998.03$ & 2.32 & 13.63 & 17.84 & 1.31 & 2.87 & Efisien \\
\hline Deiyai & $385,758.66$ & $780,222.61$ & 2.02 & 12.74 & 19.06 & 1.50 & 3.11 & Efisien \\
\hline Kota Jayapura & $9,296,001.57$ & $20,487,160.70$ & 2.20 & 12.99 & 14.54 & 1.12 & 3.63 & Efisien \\
\hline Provinsi Papua & $41,701.34$ & $139,714.31$ & 3.35 & 12.71 & 12.20 & 0.96 & 3.03 & Efisien \\
\hline
\end{tabular}

Sumber: BPS Provinsi Papua, 2017 (data diolah) 


\section{b) ICOR Sektoral Provinsi Papua}

Jika ditelusuri berdasarkan angka ICOR, dapat dikatakan bahwa sektor industri tergolong sebagai sektor yang paling tidak efisien dalam perekonomian wilayah Papua. Oleh karena untuk menciptakan kenaikan nilai tambah regional sebanyak 1 rupiah dibutuhkan peningkatan investasi di sektor industri sekitar 6.1891 rupiah.

Beda halnya dengan sektor perikanan yang kelihatan menjadi sektor paling efisien di Provinsi Papua, oleh karena memiliki ICOR terrendah yakni sebesar 1.1440, dengan kata lain untuk meningkatkan nilai tambah regional sebesar 1 rupiah, hanya dibutuhkan investasi di sektor perikanan sebesar 1.1440 rupiah.

Semestinya dengan penggunaan teknologi yang padat modal dalam sektor industri, efisiensi produksi dapat dihasilkan lebih tinggi dibandingkan dengan sektor perikanan yang lebih mengarah kepada padat karya. Akan tetapi di Papua kondisinya sangat bertolak belakang, sektor industri malah yang menjadi sektor paling tidak efisien bagi investor.

Tabel 6.

ICOR Sektoral Papua, 2016

\begin{tabular}{|l|c|c|}
\hline \multicolumn{1}{|c|}{ Sektor } & Marjinal & ICOR \\
\hline Tanaman Perkebunan & 0.2998 & 3.3352 \\
\hline Perikanan & 0.8742 & 1.1440 \\
\hline Pertanian/Peternakan & 0.3554 & 2.8135 \\
\hline Kehutanan & 0.4151 & 2.4091 \\
\hline Pertambangan & 0.2204 & 4.5378 \\
\hline Industri & 0.1616 & 6.1879 \\
\hline Perhotelan/Pariwisata & 0.3872 & 2.5826 \\
\hline Jasa Lain & 0.2024 & 4.9412 \\
\hline Papua & 0.2366 & 4.2262 \\
\hline
\end{tabular}

Sumber: Badan Penanaman Modal dan Pelayanan Terpadu Satu Pintu Provinsi Papua, 2017 (data diolah)

Dimana berdasarkan standar nilai yang menggambarkan suatu sektor itu dikatakan efisien bila mempunyai ICOR lebih kecil atau sama dengan 4, maka dapat digeneralisasikan bahwa sektor industri di Provinsi Papua mengalami kebocoran sebesar $35.36 \%$ akibat kinerja investasinya yang 
sangat tidak efisien. Angka kebocoran sebesar ini didapat dengan perhitungan : [1-(4/6.1891)] x 100\% $=35.36 \%$.

Meskipun tidak besar, namun dengan angka ICOR yang masih lebih tinggi dibandingkan angka normal, yakni sebesar 4.2262 menandakan bahwa perekonomian wilayah Papua selama ini rata-rata mengalami kebocoran sebesar 5.35\% dari investasi yang ditanamkan. Beberapa sektor ekonomi lainnya yang tergolong tidak efisien adalah sektor pertambangan yang mempunyai ICOR sebesar 4.5378 dan sektor jasa sebesar 4.9412. Kedua sektor ini masing-masing memberi kontribusi terhadap tingkat kebocoran perekonomian wilayah Papua rata-rata sebesar $11.85 \%$ yang berasal dari sektor pertambangan, dan sebesar $19.05 \%$ dari sektor jasa.

Berikut ini adalah perkiraan target pertumbuhan investasi di Provinsi papua sampai dengan tahun 2018.

Tabel 7.

Perkiraan Target Pertumbuhan Investasi

\begin{tabular}{|l|c|c|c|}
\hline \multicolumn{1}{|c|}{ Sektor } & $\begin{array}{c}\text { Target } \\
\text { Pertumbuhan } \\
2018\end{array}$ & ICOR & $\begin{array}{c}\text { Target } \\
\text { Pertumbuhan } \\
\text { Investasi } \\
2018\end{array}$ \\
\hline Tanaman Perkebunanan & 6.25 & 3.34 & 20.85 \\
\hline Perikanan & 4.15 & 1.14 & 4.75 \\
\hline Pertanian & 6.42 & 2.81 & 18.06 \\
\hline Kehutanan & 2.35 & 2.41 & 5.66 \\
\hline Pertambangan & 3.94 & 4.54 & 17.88 \\
\hline Industri & 4.21 & 6.19 & 26.05 \\
\hline Perhotelan/Periwisata & 9.23 & 2.58 & 23.84 \\
\hline Jasa Lain & 8.10 & 4.94 & 40.04 \\
\hline Papua & 8.00 & 4.23 & 33.81 \\
\hline
\end{tabular}

Sumber: Badan Penanaman Modal dan Pelayanan Terpadu Satu Pintu Provinsi Papua, 2017 (data diolah)

\section{STRATEGI PENGEMBANGAN INVESTASI}

\section{A. Isu-Isu Strategis}

Beberapa faktor yang menyebabkan masih rendahnya minat investor ke Papua, rendahnya rasio pencapaian, terbatasnya komoditi unggulan investasi, tingginya ketimpangan investasi antarsektor dan antarwilayah antara lain sebagai berikut : 1) Hak ulayat sampai saat ini masih dianggap 
sebagai ancaman, bukannya tantangan yang harus dihadapi. Kondisi ini mengakibatkan pemberian lahan kepada investor masih memerlukan proses kesepakatan yang panjang; 2) Untuk menempatkan investor, masih terkendala dengan izin pelepasan kawasan yang masih menjadi kewenangan Kementerian Kehutanan (Pusat); 3) Kurangnya insentif fiskal yang dapat mendorong investasi.

Provinsi Papua relatif tertinggal dalam menyusun insentif investasi, termasuk dalam bidang perpajakan dan retribusi, serta Perda lainnya yang dapat menarik investasi di Papua; 4) Keterbatasan akses pengusaha UMKM terhadap modal. Kegiatan penanaman modal di Papua selama ini lebih dominan pada pengembangan usaha yang bersifat eksploitatif sumberdaya alam dan belum mengarah pada pengembangan manufaktur yang berbasis pada kemampuan penguasaan teknologi; 5) Terbatasnya infrastruktur yang menghambat distribusi produk ke tempat pemasaran, dan bahan baku ke tempat produksi.

Kondisi ini akhirnya menyebabkan biaya transportasi menjadi sangat tinggi, sehingga membebankan para investor; 6) Tingginya tingkat kemahalan, yang memaksa investor harus membebankannya pada harga produk barang/jasa yang dipasarkan. Kondisi ini pada akhirnya juga mengurangi daya saing produk; 7) Lemahnya Tatrawil (Tataran Transportasi Wilayah) di tingkat provinsi dan Tatralok (Tataran Transportasi Lokal) di tingkat kabupaten yang menyebabkan tidak optimalnya sistem jaringan konektivitas dan distribusi barang/ jasa; 8) Ketersediaan tenaga kerja lokal yang terampil dan bependidikan cukup baik masih sangat terbatas, sehingga investor harus mendatangkan tenaga kerja dari luar dengan biaya yang lebih mahal; 9) Belum maksimalnya perhatian pemerintah provinsi dalam upaya mendukung peningkatan investasi didaerah-daerah pegunungan dan dataran sulit akses, misalkan kurang tersedianya data potensi Papua yang akurat, masih adanya birokrasi yang panjang dalam pengurusan perizinan sektoral, dan kurangnya pembinaan terhadap pengusaha-pengusaha lokal; 10) Pengembangan komoditi unggulan yang berbasis lahan masih 
mendominasi dalam perencanaan investasi, sehingga sering berbenturan dengan tata ruang wilayah. Dalam hal ini kapasitas aparatur perencana pembangunan dan investasi masih rendah untuk mengoptimalkan tata ruang wilayah yang telah dibuat sebelumnya.

\section{B. Sasaran Peningkatan Investasi Di Provinsi Papua}

Sasaran yang hendak dicapai dalam upaya peningkatan investasi di Provinsi Papua adalah sebagai berikut: 1) Meningkatnya investasi di wilayahwilayah yang menjadi pusat pertumbuhan baru yang tersimpul pada masingmasing wilayah adat; 2) Meluasnya investasi pada sektor-sektor yang potensial dengan fokus pada prioritas pengembangan komoditas unggulan; 3) Adanya insentif atau iklim investasi yang kondusif; 4) Terwujudnya kepastian hukum dalam bentuk sinkronisasi peraturan perundang-undangan antara pusat dan daerah, antardaerah, dan antarwilayah adat; 5) Meningkatnya surplus perdagangan Papua, baik perdagangan antar wilayah maupun ekspor; 6) Meningkatnya muatan lokal yang berbasis kearifan lokal pada produk-produk unggulan investasi; 7) Menurunnya biaya ekonomi tinggi; 8) Optimalnya pemanfaatan tata ruang dalam mendukung pengembangan investasi.

\section{Strategi Peningkatan Investasi Di Provinsi Papua}

Berdasarkan hasil analisis faktor-faktor eksternal dan internal yang terbagi atas 4 kuadran sebagaimana yang terbentuk dalam matriks SWOT maka dapat disusun beberapa strategi guna mewujudkan sasaran yang telah ditetapkan sebagai berikut : 1) Strategi pengembangan kawasan dan pusatpusat pertumbuhan yang baru. Strategi ini dilaksanakan dengan meningkatkan pembangunan infrastruktur transportasi darat pada kawasankawasan sentra produksi yang potensial, dan menarik investor secara maksimal; 2) Strategi pengembangan transportasi terpadu. Strategi ini dilaksanakan dengan mengembangkan integrasi antara transportasi darat, laut dan udara, yang berguna untuk meningkatkan konektifitas antara tempat 
produksi dengan pengiriman bahan baku, serta tempat produksi dengan pasar.

Selain itu juga memperkuat Tatrawil dan Tatralok; 3) Strategi optimalisasi potensi komoditi unggulan investasi berbasis tata ruang; 4) Strategi penguatan dan pengembangan kapasitas kelembagaan ekonomi, khususnya lembaga pasar, lembaga kemitraan (output dan input), dan kelompok kerja; 5) Strategi optimalisasi kepastian hukum dalam berinvestasi. Terutama untuk kepastian hukum mengenai pelepasan tanah adat, dan pengurusan sertfikat tanah; 6) Strategi peningkatan muatan lokal (local content) dalam setiap produk-produk investasi.

\section{Program-Program Prioritas}

Adapun perumusan program memperhatikan hal-hal sebagai berikut: 1) Program disusun dalam kerangka strategis pembangunan jangka menengah daerah, yaitu memperhitungkan bahwa program yang dirumuskan merupakan salah satu elemen dalam pencapaian rencana pembangunan jangka menengah daerah; 2) Untuk meningkatkan rasa tanggung jawab atas pencapaian kinerja program, dalam penyusunan program melibatkan SKPD yang terkait; 3) Penamaan program menggunakan kalimat sederhana, ringkas mudah dimengerti sehingga dapat dijabarkan kedalam kegiatan; dan 4) Program didefinisikan sebagai cara untuk mencapai target kinerja sasaran melalui strategi dan arah kebijakan.

Sesuai dengan hasil pengamatan sebelumnya, perumusan program dan kegiatan ini ditujukan untuk mencapai beberapa aspek pengembangan komoditi unggulan di Provinsi Papua yaitu : (1) aspek pemasaran dan tata niaga, (2) aspek kemitraan usaha, (3) aspek sumber daya manusia, (4) aspek produksi, permodalan dan nilai tambah produk unggulan, (5) aspek kelembagaan ekonomi, dan (6) aspek teknologi dan lingkungan. Adapun program-program prioritas dalam kebijakan percepatan investasi di Provinsi Papua, sebagai berikut: 1) Program Peningkatan Promosi Dan Kerjasama 
Investasi; 2) Program Peningkatan Iklim Investasi Dan Realisasi Investasi; 3) Program Penyiapan Potensi Sumber Daya, Sarana Dan Prasarana Daerah;

4) Program Pemantapan Koordinasi Perencanaan Penanaman Modal; 5) Program Pengendalian Pelaksanaan PMDN Dan PMA; 6) Program Pengembangan Sumberdaya Aparatur BKMPD; 7) Program Pengembangan/Identifikasi Potensi Dan Peluang Investasi Di Daerah; 8) Program Promosi Dan Kerjasama Penanaman Modal; 9) Program Penyusunan Dan Penetapan Kebijakan Iklim Investasi Dan Iklim Usaha Di Daerah; 10) Program Peningkatan/Mengintensifkan Pelayanan Perijinan Penanaman Modal; 11) Program Peningkatan Kegiatan Pemantauan, Pembinaan dan Pengawasan Pelaksanaan Penanaman Modal

\section{SIMPULAN DAN REKOMENDASI}

\section{Simpulan}

Terlihat bahwa secara spasial, dari 29 kabupaten/kota yang telah dihitung ICOR-nya teridentifikasi ada 20 daerah yang dianggap memiliki low cost to investment karena mempunyai ICOR yang rendah. Ke-20 daerah yang dimaksud adalah Kabupaten Merauke, Jayawijaya, Jayapura, Nabire, Kepulauan Yapen, Biak Numfor, Paniai, Mimika, Boven Digoel, Waropen, Mamberamo Raya, Nduga, Lanny Jaya, Yalimo, Puncak, Dogiyai, Intan Jaya, Deiyai dan Kota Jayapura. Sedangkan daerah lainnya, karena memiliki ICOR yang tinggi yaitu diatas angka moderat, maka dinilai tidak efisien atau high cost to investment, daera-daerah yang dimaksud adalah Kabupaten Supiori, Pegunungan Bintang, Puncak Jaya, Yahukimo, Tolikara, Asmat, Keerom, Mappi, Sarmi, dan Mamberamo Tengah.

Sedangkan kebutuhan untuk memperoyeksikan investasi regional di masa mendatang dalam perencanaan pembangunan ekonomi wilayah menjadikan ICOR sebagai alat yang paling penting untuk dihitung dan dianalisis. Selain digunakan untuk proyeksi investasi ICOR juga dapat dimanfaatkan untuk mengkaji kinerja kegiatan investasi dari suatu sektor produksi apakah berjalan efisien atau tidak. 
Berdasarkan analisis ICOR ini diperoleh temuan bahwa selama periode 2012-2016 sektor ekonomi di Provinsi Papua yang paling tidak efisien adalah sektor industri yang mempunyai ICOR tertinggi yakni sebesar 6.1879, sehingga diperkirakan sektor ini telah menyebabkan perekonomian wilayah Papua mengalami kebocoran sebesar 35.36\%. Beberapa sektor lainnya yang dianggap turut memberi kebocoran ekonomi di Provinsi Papua selama ini adalah sektor pertambangan dan jasa.

Sebagian besar sektor ekonomi berbasis pertanian, terutama perkebunan, perikanan, kehutanan dan pertanian/peternakan, terindikasi memiliki tingkat efisiensi yang cukup tinggi, dikarenakan seluruh sektor tersebut mempunyai ICOR yang sangat rendah dengan rata-rata di bawah 4 . Merujuk kepada besaran angka ICOR ini akhirnya digeneralisasikan bahwa upaya untuk meningkatkan investasi regional Provinsi Papua di masa mendatang sebaiknya diarahkan kepada sektor-sektor berbasis pertanian.

Terutama sekali pada sektor perikanan yang menjadi sektor produksi paling efisien menjalankan investasinya selama ini. Secara keseluruhan angka ICOR rata-rata Provinsi Papua relatif tinggi yakni mencapai 4.2262, sehingga terindikasi bahwa perekonomian Provinsi Papua selama ini mengalami kebocoran sebesar $5.35 \%$ dari total investasi yang ditanamkan. Berdasarkan skenario pertumbuhan ekonomi tahun 2018 menunjukkan bahwa investasi di sektor pertambangan, industri dan jasa lainnya membutuhkan pertumbuhan yang sangat tinggi.

Kondisi ini disebabkan karena sektor-sektor tersebut tidak efisien dengan nilai ICOR diatas angka moderat, sehingga untuk mencapai target pertumbuhan di tahun 2018 sebesar $8 \%$ sesuai target RPJMD, diperlukan pertambahan investasi dengan tingkat pertumbuhan yang sangat tinggi, ratarata di atas $20 \%$ per tahun. Sedangkan untuk sektor tanaman perkebunan, perikanan, pertanian tanaman pangan, kehutanan, dan perhotelan atau pariwisata, semuanya hanya membutuhkan pertumbuhan investasi berkisar diantara $4,75 \%-23,84 \%$. 
Berdasarkan hasil analisis deskriptif kualitatif dan FGD teridentifikasi beberapa faktor yang dapat mempengaruhi perkembangan investasi di Provinsi Papua yaitu : hak ulayat, izin pelepasan kawasan yang masih menjadi kewenangan pemerintah pusat, insentif fiskal, akses pengusaha UMKM terhadap modal, infrastruktur, tingkat kemahalan, sistem Tataran Transportasi Wilayah dan Tataran Transportasi Lokal, Ketersediaan tenaga kerja lokal yang terampil dan bependidikan, ketersediaan data potensi Papua yang akurat, birokrasi dalam pengurusan perizinan sektoral, pembinaan terhadap pengusaha-pengusaha lokal, dan pengembangan komoditi unggulan yang berbasis lahan masih mendominasi dalam perencanaan investasi, sehingga sering berbenturan dengan tata ruang wilayah.

\section{Rekomendasi}

Setiap daerah kabupaten/kota yang teridentifikasi tidak efisien untuk berinvestasi perlu mengendalikan angka ICOR-nya untuk berada pada interval angka yang moderat, dimana hal ini dapat dilakukan dengan cara menekan high cost to investment seoptimal mungkin, sehingga mampu meningkatkan gairah investasi bagi para pemilik modal.

Demikian juga untuk beberapa sektor ekonomi yang tidak efisien diperlukan kebijakan-kebijakan sektoral yang efektif guna mengatasi berbagai kendala investasi yang dapat mengurangi daya saing Provinsi Papua seperti mengatasi kendala hak ulayat, infrastruktur yang kurang memadai, akses modal dan pasar yang rendah, dan kualitas tenaga kerja lokal yang belum sesuai dengan kebutuhan pasar.

Selain itu optimalisasi pemanfaatan tata ruang wilayah pada 29 kabupaten/kota yang dapat dilakukan dengan mengubah paradigma investasi berbasis lahan menjadi investasi berbasis tata ruang, yang tentu saja dengan upaya mengoptimalkan ruang yang tersedia tanpa melanggar ketetapan penggunaan yang berlaku.

Hal tersebut dapat dilakukan dengan melakukan berbagai inovasi dalam kegiatan-kegiatan investasi sektoral seperti pengembangan investasi 
di sektor industri kreatif, pariwisata, pertanian (tanaman hidroponik, atau penggunaan bibit unggul), dan sebagainya.

\section{DAFTAR PUSTAKA}

Adisasmita, R. 2010. Teori Pertumbuhan Wilayah. Jurusan Teknik Perkapalan. Makassar: Universitas Sultan Hassanuddin.

Ambarita, F. 2012. Analisis Perkembangan Incremental Capital Output Ratio (ICOR) Sektor Industri Provinsi Daerah Istimewa Yogyakarta Tahun 2001 - 2008. Tesis. Yogyakarta: UPN Veteran.

BKPM. 2016. Perkembangan Persetujuan dan Izin Usaha Tetap Penanaman Modal. Badan Koordinasi Penanaman Modal, Jakarta.

Bank Indonesia. 2016. Kajian Ekonomi dan Keuangan Regional. Laporan Nusantara, Agustus 2016. Vol 11 Nomor 3. Bank Indonesia.

BAPPEDA Provinsi Jawa Timur dan Fakultas Ekonomi Universitas Brawijaya. 2009. Perencanaan kebijakan Percepatan Investasi di Jawa Timur Wilayah Utara Dalam Rangka meningkatkan Pertumbuhan Ekonomi Jawa Timur. Excecutive Summary.

BPS Provinsi Papua. 2017. Papua Dalam Angka Tahun 2017. Badan Pusat Statistik Provinsi Papua, Jayapura. . 2016. Produk Domestik Regional Bruto Kabupaten Kota se-Provinsi-Papua-Menurut-Lapangan-Usaha-2012-2016. Badan Pusat Statistik Provinsi Papua, Jayapura.

Deputi Bank Indonesia. 2015. Kajian Identifikasi Indikator Sukses Klaster. Bank Indonesia, Jakarta.

Djony, E. 2017. 2017 ICOR Memburuk, Tanda Investasi tak Efisien. Nusantara News. https://nusantara.news/icor-memburuk-tandainvestasi-tak-efisien/

Dwiastuti, R., Sujarwo dan R. Asmara. 2009. Pemetaan ICOR Komoditas Pertanian Di Wilayah Indonesia Bagian Tengah Dalam Rangka Revitalisasi Pertanian. Jurnal IImu-IImu Sosial 21 (1) : 21-32.

Domar, E. 1946. Capital expansion, rate of growth, and employment. Econometrica 14 (2) : 137 - 147.

Hadi, P.U., Helena J. Purba, P. Simatupang, J. Situmorang, dan T.S. Wahyudi. 2010. Analisis Dampak Investasi Pertanian terhadap Kinerja Sektor Pertanian. Laporan Hasil Penelitian. Pusat Sosial Ekonomi dan Kebijakan Pertanian. Bogor.

Harrod, R.F. 1939. An essay in dynamic theory. The Economic Journal 49 (193) : 14 - 33.

Ilham, M. 2013. Analisis Pengaruh Pengeluaran Pemerintah Kota, ICOR , Investasi Terhadap Perekonomian Daerah Kota Tebing Tinggi. Tesis. Medan: Sekolah Pascasarjana Universitas Sumatera Utara. 
Jhingan, M.L, 2003. Ekonomi Pembangun an dan Perencanaan. Jakarta: PT Raja Grafindo Persada.

Muslimin. 2002. Metodologi Penelitian Bidang Sosial. Penerbit Bayu Media dan UMM Press. Malang.

Nugroho, I. dan N. Hanani. 2007. Studi Investasi Untuk Pengembangan Komoditi Pertanian di Propinsi Lampung: Pendekatan InputOutput. Jurnal Ekonomi 12(1):32-39.

Rengkuti, F. 2006. Analisis SWOT Teknik Membedah Kasus Bisnis. Penerbit PT. Gramedia Pustaka Utama, Jakarta.

Samuelson, Paul A dan William D. Nordhaus. 2001. Makro-Ekonomi, Edisi Keempatbelas. Jakarta: Erlangga.

Sadeghi, Z., M. Nikzad, and M.B. Todsheki. 2014. Investigating effect of development of agricutural, industrial, service and oil revenue to ICOR of agricultural sector. International Journal of Agricultural Management and Development 4(3):227

Saleh, I, H. Varmazyari, and H. Moslemzadeh. 200 8. Investigation the $p$ otential of i nvestment in a gricultural s ector of Iran (Emphasizing on $\mathrm{n}$ ational $\mathrm{d}$ evelopment $\mathrm{p}$ rograms). American - Eur asian $\mathrm{J}$. Agric. \& Environ. Sci. 2 (Supple 1) : 108 - 112.

Todaro, MP. (2004). Pembangunan Ekonomi Di Dunia Ketiga. Jakarta : Erlangga. 